\title{
Mass Tort Litigation: A Statutory Solution to the Choice of Law Impasse
}

\author{
Paul S. Bird
}

\section{INTRODUCTION}

Because mass torts ${ }^{1}$ are often multistate, ${ }^{2}$ they generate conflict of laws questions $s^{3}$ that current choice of law doctrine does not resolve equitably and efficiently. "The Supreme Court's decision in Klaxon Co. v. Stentor

1. In this Note, the term "mass tort" refers to single-incident, multiple-victim accidents such as airplane, bus, or train crashes, see, e.g., In re Air Crash Disaster at Washington, D.C. on January 13, 1982, 559 F. Supp. 333 (D.D.C. 1983) [hereinafter Washington, D.C. Air Crash], structural failures, see, e.g., In re Federal Skywalk Cases, 680 F.2d 1175 (8th Cir. 1982), or non-recurring mass exposures to toxic chemicals where the causal connection between the toxins released and harm is clear, see, e.g., In re Union Carbide Corp. Gas Plant Disaster at Bhopal, India in Dec. 1984, 634 F. Supp. 842 (S.D.N.Y. 1986) [hereinafter Gas Plant Disaster at Bhopal].

Some mass disasters do not neatly fit into any of these categories. Consider, for example, the asbestos and Dalkon Shield claims that arose from exposure to or use of dangerous or defective products over many years in different parts of the country. Such accidents lack a fixed time and space fact pattern common to all claimants and thus may require alternate compensation systems for the efficient and fair resolution of the damage claims they generate. See, e.g., Elliot, Goal Analysis Versus Institutional Analysis of Toxic Compensation Systems, 73 Geo. L. Rev. 1357, 1369 (1985) (not all toxic torts fit "pattern required by civil cases for damages in court"). This Note addresses mass torts in which the causal relationship between incident and injury is sufficiently clear to permit their fair and efficient resolution in civil courts.

2. Mass torts can be "multistate" in two senses: They may injure people domiciled in different states; they may also generate claims for personal injury and wrongful death in more than one state.

3. See, e.g., In re Air Crash Disaster Near Chicago, Ill. on May 25, 1979, 644 F.2d 594 (7th Cir. 1981) (hereinafter Chicago Air Crash] (conflicts questions concerning punitive damages in wrongful death actions); In re "Agent Orange" Prod. Liab. Litig., 580 F. Supp. 690 (E.D.N.Y. 1984) [hereinafter Agent Orange] (conflicts questions concerning liability, government contract defense, and punitive damages); Washington, D.C. Air Crash, 559 F. Supp. 333 (D.D.C. 1983) (conflicts questions concerning products liability and punitive damages); In re Air Crash Disaster at Boston, Mass. on July 31, 1973, 399 F. Supp. 1106 (D. Mass. 1975) [hereinafter Boston Air Crash] (conflicts questions concerning amount recoverable for wrongful death); In re Paris Air Crash of March 3, 1974, $399 \mathrm{~F}$. Supp. 732 (C.D. Cal. 1975) [hereinafter Paris Air Crash] (conflicts questions concerning type and measure of damages for wrongful death).

4. See infra notes $45-55$ and accompanying text. 


\section{Electric Manufacturing $\mathrm{Co}^{\mathrm{s}}$ requires a federal court sitting in diversity} to apply the choice of law rule of the state in which it sits. ${ }^{6}$ Thus, a federal court presiding over multidistrict mass tort litigation must first discover and then apply numerous and varying state choice of law rules. As a result, different substantive laws frequently govern the identical claims of parties injured in the same mass accident, simply because they reside in different states. ${ }^{7}$ This Note argues that Klaxon should not apply in mass tort litigation. ${ }^{8}$

The federal courts need more than freedom from state choice of law rules, ${ }^{9}$ however, if they are to adjudicate fairly and efficiently claims arising from mass torts in a modern technological society. The federal courts also require a set of guiding choice of law principles that the Supreme Court, because of its infrequent and circumscribed ${ }^{10}$ review of choice of

5. 313 U.S. 487 (1941).

6. In Klaxon, the Court held that where a federal court's jurisdiction over an action brought in Delaware for breach of contract was based on diversity of citizenship, the court was not free to determine the applicability of a New York interest statute in accordance with its own conception of the better view of the law but was bound to follow the conflict of laws rules prevailing in Delaware's state courts. The Court rested its decision on the Erie doctrine, saying, "Otherwise, the accident of diversity of citizenship would constantly disturb equal administration of justice in coordinate state and federal courts sitting side by side." 313 U.S. at 496 (citing Erie R.R. v. Tompkins, 304 U.S. 64 (1938)); see also Day \& Zimmermann, Inc. v. Challoner, 423 U.S. 3 (1975) (per curiam) (reaffirming Klaxon).

7. See infra note 47 and accompanying text.

8. Klaxon has been widely criticized on the grounds that the decision was not required by the Constitution or the Rules of Decision Act, 28 U.S.C. $\$ 1652$ (1982), and represents an unwarranted extension of Erie into the area of choice of law. See R. Bridwell \& R. Whitten, The Constitution and the Common LAw 135 (1977); E. Scoles \& P. HaY, Conflict of Laws 112 (1982); C. WRIGHT, The LAw of Federal Courts 367-70 (4th ed. 1983); Baxter, Choice of Law and the Federal System, 16 STAN. L. REv. 1, 32 (1963) (describing Court's decision in Klaxon: "It so held without making the most cursory reference to the language, history, or purpose of the Rules of Decision Act or the grant of diversity jurisdiction or to the history or purpose of the federal courts in general."); Hill, The Erie Doctrine and the Constitution, 53 Nw. U.L. REv. 427, 444-45 (1958); Horowitz, Toward A Federal Common Law of Choice of Law, 14 UCLA L. REv. 1191 (1967); Korn, The Choice-of-Law Revolution: A Critigue, 83 Colum. L. Rev. 772, 971 (1983); Trautman, The Relation Between American Choice-of-Law and Federal Common Law, 41 LAw \& CONTEMP. Probs., Spring 1977, at 105, 120; Weintraub, The Erie Doctrine and State Conflict of Laws Rules, 39 IND. L.J. 228, 246-48 (1964).

Klaxon was decided in the context of a bilateral dispute nearly 30 years before the advent of multiparty multidistrict litigation. It satisfied Erie's desire for uniform application of state substantive law whether in state or federal court. Mass tort litigation, on the other hand, presents a competing need for the application of a uniform standard to all plaintiffs whose claims, although originating in several states, have been consolidated in a single state.

9. Professors Miller and Crump have recently suggested that federal courts be free to make their own choice of law decisions when exercising a proposed statutory multiparty, multistate jurisdiction. See Miller \& Crump, Jurisdiction and Choice of Law in Multistate Class Actions After Phillips Petroleum Co. v. Shutts, 96 YALE L.J. 1, 78 (1986). This Note addresses the kinds of cases in which federal courts should have such authority under ordinary diversity jurisdiction and proposes the set of choice of law principles a federal statute conferring such authority should encompass.

10. Since conflict of laws rules are matters of state law, the few Supreme Court decisions in this field address only the constitutional limits on choice of law. See, e.g., Phillips Petroleum Co. v. Shutts, 105 S. Ct. 2965 (1985); Allstate Ins. Co. v. Hague, 449 U.S. 302 (1981); Nevada v. Hall, 440 U.S. 410 (1979); see also cases discussed infra note 71 (constitutional limits on choice of law); $c$. Day \& Zimmermann, Inc. v. Challoner, 423 U.S. 3 (1975) (reversing lower federal court's decision not to 
law decisions, is unlikely to articulate. ${ }^{11}$ This Note therefore proposes that Congress enact a choice of law statute enabling and directing federal courts presiding over mass tort litigation to make choice of law decisions that will promote both equity and efficiency.

The equity concerns beneath this proposal are twofold. First, current law often precludes equity among plaintiffs in mass tort suits because different substantive laws likely will be applied to identical claims of similarly situated parties. Equity among plaintiffs requires that a single rule of decision apply to all like claims. ${ }^{12}$ Second, from society's point of view, equity requires that victims of mass torts receive prompt, adequate, and effective compensation for their injuries. ${ }^{13}$ Thus, within certain limits, the proposed statute set forth in Section III requires that a court select the most favorable substantive law available to plaintiffs. ${ }^{14}$

This Note also addresses two types of efficiency in mass tort litigation. First, the proposed statute removes choice of law barriers that discourage the use of collective adjudication in mass torts and thereby deny mass tort litigation the numerous judicial efficiencies that collective adjudication can offer. ${ }^{15}$ Second, by eliminating the requirement that a federal court follow several state choice of law rules, the proposed statute eliminates the inefficiencies this burden places on the court's choice of law decision. ${ }^{16}$

follow state conflicts rule). The Court's due process analyses generally focus on the fairness to the defendant of the choice of law decision under review and do not address the equitable treatment of plaintiffs. Furthermore, the Court has not measured choice of law decisions against the efficiency concerns raised in this Note. See infra note 41 and accompanying text. Finally, the Court has never reviewed a choice of law decision in a mass accident case.

11. Indeed, the Court's terse reversal in Day \& Zimmermann supports this assumption. In that case, an injured serviceman and the estate of a deceased serviceman sought recovery of damages based on the premature explosion of a howitzer round in Cambodia during the Vietnam War. A lower federal court sitting in diversity had declined to follow Texas' lex loci delicti choice of law rule on the theory that Cambodia, the place of the wrong, had "no interest in the case, no policy at stake." Challoner v. Day \& Zimmermann, Inc., 512 F.2d 77, 80 (5th Cir.), rev'd, 423 U.S. 3 (1975).

The Court, however, rejected the lower court's innovative approach, stating, "A federal court in a diversity case is not free to engraft onto those state [conflict of laws] rules exceptions or modifications which may commend themselves to the federal court, but which have not commended themselves to the State in which the federal court sits." 423 U.S. at 4. The Court's position evinces a manifest reluctance to prescribe the choice of law principles this Note argues are essential to fair and efficient mass tort adjudication.

12. See infra notes $50-52$ and accompanying text.

13. See infra note 49 and accompanying text.

14. See infra notes 94-97 and accompanying text.

15. See infra note 41 and accompanying text.

16. See infra note 100 and accompanying text. 


\section{Mass Tort Choice of Law Decisions Under Current Law}

\section{A. An Illustration of the Problem}

Consider the hypothetical case of a commercial airplane crash in State A during a flight from State B to State C. ${ }^{17}$ Representatives of deceased passengers file wrongful death actions against the plane manufacturer alleging inadequate instructions in the manufacturer's operating manual for the plane. ${ }^{18}$ The manufacturer built the plane in State B but is incorporated and maintains its principal place of business in State E. The plaintiffs are from four states, A through D. Although some plaintiffs from all four states file initially in State $A,{ }^{19}$ the majority file suit in their respective states of residence. ${ }^{20}$ The choice of law rules, liability standards for

17. The illustration in the text is based upon the air crash disaster cases cited above. See supra note 3. Although the choice of law problems presented by this hypothetical are considerable, the simplification of the issues and analyses that was necessary to condense these cases into a useful and intelligible example actually obscures some complexity. The actual cases involve considerably more states, countries, issues, and varied choice of law rules.

For example, in Paris Air Crash, 399 F. Supp. 732, 742 (C.D. Cal. 1975), the federal court, upon considering the choice of law rules of the twelve states from which the claims before it had been consolidated, found that five states followed a "significant contacts" analysis, sometimes interchangeably with the "governmental-interest" or "public-interest" approach, six followed lex loci delicti, and one, California, relied exclusively on the "governmental-interest" approach. Focusing on the substantive rules uncovered by this multifaceted choice of law analysis, the court found that the measure of damages recoverable also varied: "One state limits the amount to $\$ 50,000$; another, to $\$ 75,000$; four allow full recovery with varying limitations; one has full recovery plus pain and suffering and mental anguish; and five use 'compensatory' and, in some instances, 'pecuniary' (as the standard for recoveryl." Id. Applying these disparate laws would have been "chaotic, and against the faintest instinct for justice by [meting out] unequal results to those standing in the same relationship to each other and to the decedent." Id. at 741 .

Relying upon the Fifth Circuit's not-then-overruled decision in Challoner v. Day \& Zimmermann, Inc., 512 F.2d 77 (5th Cir.), rev'd, 423 U.S. 3 (1975), the court in Paris Air Crash rejected Klaxon and employed instead a single choice of law formula to guarantee that a single substantive rule would govern all claims. 399 F. Supp. at 747. This Note's proposed statute grants to federal judges the autonomy so sensibly seized in Paris Air Crash.

18. Cf. Washington, D.C. Air Crash, 559 F. Supp. 333, $345-46$ (D.D.C. 1983) (defects in manufacturer's operating manual governed by strict liability standard under District of Columbia law, by negligence standard under Washington state law).

19. For various strategic reasons, some plaintiffs may deem it more advantageous to file suit in the district where the crash occurred. See, e.g., Boston Air Crash, 399 F. Supp. 1106, 1115 (D. Mass. 1975) (claimants from Virginia, Kentucky, and New Hampshire file initially in Massachusetts, site of crash).

20. Assuming the manufacturer does substantial business in States $A$ through $D$-for example, each state has one or more interstate airports-such business activities would constitute "minimum contacts" for purposes of obtaining personal jurisdiction over the manufacturer in all these states. International Shoe Co. v. Washington, 326 U.S. 310 (1945); see also World-Wide Volkswagen Corp. v. Woodson, 444 U.S. 286 (1980) (requiring link between defendant's conduct and forum such that defendant could reasonably foresee suit in that forum).

For diversity purposes, a corporation is deemed to be a citizen of both its state of incorporation and the state where it maintains its principal place of business. 28 U.S.C. $\S 1332$ (c) (1982). A corporation sued in one of those two states may not remove the case to federal court. 28 U.S.C. $\$ 1441$ (b) (1982). Thus, if under the hypothetical posed in the text, some of the claimants were citizens of State E, they would not be able to sue the plane manufacturer in federal court, because there would be no diversity of citizenship. The requirement of complete diversity is, however, statutory rather than constitutional and can, therefore, be eliminated by Congress. See State Farm Fire \& Casualty Co. v. Tashire, 386 


\section{Mass Tort Litigation}

defective manuals, and measure of damages rules in the five states are as follows: $:^{21}$

\section{TABLE I}

\section{State Ghoice of Law Rule}

$\begin{array}{cc}\text { A } & \text { governmental interest } \\ \text { B } & \text { Leflar } \\ \text { C } & \text { lex loci delicti } \\ \text { D } & \text { comparative impairment } \\ \text { E } & \text { governmental interest }\end{array}$

Standard of Liability Measure of Damages

negligence
strict liability
strict liability
strict liability
negligence

unlimited

unlimited

limited

limited

limited

Under 28 U.S.C. $\S 1404^{22}$ and 28 U.S.G. $\S 1407,{ }^{23}$ the scattered actions would be transferred and consolidated for pre-trial purposes before the district court in State A. ${ }^{24}$ The Supreme Court's decision in Van Dusen v. Barrack $^{\mathbf{2 5}}$ requires a transferee court to apply the law of the transferor

U.S. 523 (1967) ("minimal diversity" permissible under article III); see also D. LouISELL, G. Hazard \& C. Tait, Pleading and Procedure: State and Federal Cases and Materials 469 (5th ed. 1983) (complete diversity a statutory requirement). Congress should remove this requirement to permit complete joinder in mass tort cases.

21. The choice of law methodologies listed in Table I are discussed infra notes 28-39 and accompanying text.

22. "For the convenience of parties and witnesses, in the interest of justice, a district court may transfer any civil action to any other district or division where it might have been brought." 28 U.S.C. $\S 1404(\mathrm{a})$ (1982).

23. "When civil actions involving one or more common questions of fact are pending in different districts, such actions may be transferred to any district for coordinated or consolidated pre-trial proceedings." 28 U.S.C. $\S 1407$ (a) (1982). Transfer under $\S 1407$ (a) may be made by the Judicial Panel on Multidistrict Litigation upon the panel's own initiative or by motion filed with the panel by a party. 28 U.S.C. $\S 1407$ (c) (1982).

24. A general rule of the Judicial Panel on Multidistrict Litigation is that the most efficient and expeditious resolution of domestic air disaster litigation is best achieved by transferring all actions to the district of the situs of the crash. In re Air Crash Disaster Near Natchitoches Parish, La. on Sept. 20, 1973, 407 F. Supp. 1401, 1402 (J.P.M.D.L. 1976).

Although $\S 1407$ was intended to apply only to pre-trial proceedings, Rule 11(b) of the Panel's Rules of Procedure gives the transferee court the authority to transfer all cases to itself for all purposes under $\S 1404$. R. Proc. J.P.M.D.L. 11(b), 28 U.S.C. fol. $\S 1407$ (1982). Thus, in practice, most multidistrict cases are disposed of in a single court. See, e.g., In re Air Crash Near Duarte, Cal., on June 6, 1971, 357 F. Supp. 1013, 1016 (C.D. Cal. 1973) (explaining transferee court's $\$ 1404$ transfer of all actions to itself on grounds that remanding actions to different transferor courts "may produce different results in different districts. Such a result in this case is certainly 'not in the interest of justice" "); see also In re New York City Mun. Sec. Litig., 572 F.2d 49, 51 (2d Cir. 1978) ("Moreover the pretrial proceedings encompassed by $\S 1407$ include summary judgment, and history has indicated that once the limited transfer has occurred, the transferor district is not likely to see the case again."); D. HerR, Multidistrict LiTigation 211 (1986) ("In practice remand has proven the exception rather than the rule in multidistrict litigation."); Note, The Judicial Panel and the Conduct of Multidistrict Litigation, 87 HARV. L. REv. 1001 (1974) (discussing infrequency of retransfers to transferor courts). Of the 12,484 multidistrict cases remanded or terminated by transferee courts between 1968 and 1985, less than 25\% were remanded to the transferor districts. ANNUAL REPORT of the DiRector of the Administrative Office of THE UNITEd States Courts (1985), reprinted in Records of the Proceedings of the Judicial Conference of the United States 168 (1985).

25. 376 U.S. 612 (1964). 
court in cases transferred under the federal transfer statutes. ${ }^{26}$ Therefore, the transferee court would make choice of law decisions as follows: ${ }^{27}$

\section{Claims Brought Originally in State A: Employing State A's} governmental-interest ${ }^{28}$ approach, the transferee court would choose the applicable law from among those states whose contacts create an "interest" in having their law applied. Because residence is deemed to create such an interest, ${ }^{2 \theta}$ the transferee court would consider the laws of States A, B, G, and D, the claimants' domiciles, and of State E, the manufacturer's principal place of business and place of incorporation. ${ }^{30}$ There would be no conflict concerning the applicable standard of liability with respect to claimants from State A since both States A and E employ a negligence standard requiring proof of manufacturer's fault. For claimants

26. The basic rationale underlying Van Dusen is that when jurisdiction over the defendant is proper in the transferor court, the defendant should not be able to avoid the law of that state simply by transferring the case to another district. Several circuit courts have held, however, that if jurisdiction over the defendant was lacking in the original forum, the transferee court must apply the law of the state in which it sits, regardless of which party requested transfer. See, e.g., Gonzalez v. Volvo of America Corp., 734 F.2d 1221, 1223 (7th Cir. 1984); Roofing \& Sheet Metal Serv., Inc. v. La Quinta Motor Inns, 689 F.2d 982, 992 (11th Cir. 1982); Ellis v. Great Southwestern Corp., 646 F.2d 1099, 1110 (5th Cir. Unit A June 1981); Martin v. Srokes, 623 F.2d 469, 472 (6th Cir. 1980). Conversely, the same courts have held that if jurisdiction was proper, the state law of the original forum should govern the action, regardless of which party requested transfer. Gonzalez, 734 F.2d at 1224; La Quinta Motor Inns, 689 F.2d at 992-93; Martin, 623 F.2d at 473. See generally Note, Choice of Law in Federal Court After Transfer of Venue, 63 CoRnell L. REv. 149 (1977) (determination of applicable law after transfer should be based on propriety of venue and personal jurisdiction in initial forum).

Professor Weintraub offers an interesting argument critical of the requirement that a $\S 1404$ transferee court look to the law of the transferor district by noting that "the plaintiff is not 'traditionally" entitled to select an inconvenient forum. But for the flexibility that 1404(a) provides when the plaintiff has selected an inconvenient forum, the sanction might be dismissal of the complaint and with it the plaintiff's advantage in being able to select his law with his forum." Weintraub, supra note 8, at 258-59. On the other hand, deference to the law of the transferee court might create an unfair forumshopping advantage for defendants. Consistent with the thesis of this Note, the best solution would be to let the transferee district court make its own determination as to which state's law is most appropriate.

27. Van Dusen has been interpreted to require the transferee court to follow the choice of law rules of the transferor court. See, e.g., Agent Orange, 580 F. Supp. 690 (E.D.N.Y. 1984) (transferee court must follow choice of law rules of transferor court); Washington, D.C. Air Crash, 559 F. Supp. 333 (D.D.C. 1983) (same).

28. See B. Currie, Selected Essays on the Conflict of Laws (1963); Currie, Comments on Babcock v. Jackson, A Recent Development in Conflict of Laws, 63 Colum. L. REv. 1233, 1242-43 (1963). Under Professor Currie's "governmental-interest" analysis, a court's determination of whether a state has an interest in having its law applied requires analysis of the policies underlying the particular law.

29. See, e.g., Babcock v. Jackson, 12 N.Y.2d 473, 191 N.E.2d 279, 240 N.Y.S.2d 743 (1963) (applying New York law instead of Canadian guest statute where car accident occurred in Canada but both parties were New York residents). Interest analysis places near-exclusive reliance on domicile or residence as an interest-generating factor. This is apparent from the most significant contribution of interest analysis to the choice of law field: namely, the identification of "false conflicts"-cases in which, because opposing parties are residents of the same state, only that state is likely to have an interest in having its law applied. See also Boston Air Crash, 399 F. Supp. 1106, 1115 n.13 (D. Mass. 1975) (false conflict can also arise when laws of several interested states are compatible).

30. See, e.g., Washington, D.C. Air Crash, 559 F. Supp. at 343 (state of principal place of business has interest in law applied to plane manufacturer). 
from States B, C, and D, a true conflict would arise between the strict liability rules of those states and the negligence standard of State E. Professor Currie has suggested that in cases of true conflict forum law should apply. ${ }^{31}$ Assuming that State A courts follow Currie's suggestion, the transferee court would apply the negligence rule of State A to the claimants from States B, C, and D who initially filed there.

As applied to the measure of damages, this analysis would lead the transferee court to apply unlimited recovery rules to claimants from States $A$ and $B$ and limited recovery rules to claimants from States $C$ and $D$. Claimants from A and B benefit from State A's unlimited recovery law due to a true conflict with State E's law and the transferee court's consequent deferral to forum law. Conversely, because the laws of States C, D, and $\mathrm{E}$ impose limits on recovery, no conflict exists and a limited recovery law would apply to the State $\mathrm{C}$ and D claims. ${ }^{32}$

Claims Brought Originally in State B: State B courts follow Professor Leflar's choice-influencing-factors approach under which selection of the "better law" and advancement of the forum's legitimate governmental interests are the decisive factors for resolving conflicts questions. ${ }^{33}$ Under this standard, the transferee court would probably find that a State B court would prefer State B's strict liability and unlimited recovery laws to State E's negligence and limited liability rules. The transferee court would, therefore, apply State B's law to the claims filed in State B. ${ }^{34}$

Claims Brought Originally in State C: Under the traditional rule of lex loci delicti, followed in State C, a court looks to the law of the "state where the last event necessary to make an actor liable for an alleged tort" took place. ${ }^{35}$ Thus, the transferee court would find that a State C court

31. Currie, supra note 28 , at $1242-43$ ("If, upon reconsideration, the court finds that a conflict between the legitimate interests of the two states is unavoidable, it should apply the law of the forum.").

32. This illustration assumes that the states' limited recovery laws impose the same limit on recovery. Were this not the case, a court would still probably not find a true conflict and would apply the recovery limit of the claimant's state. See Currie, supra note 28, at 1242 (suggesting "more moderate and restrained interpretation of [one state's] policy or interest" in cases of "apparent conflict").

33. See Milkovich v. Saari, 295 Minn. 155, 170, 203 N.W.2d 408, 417 (1973) (compelling factors under Leflar approach are advancement of forum's governmental interest and application of better law). In addition to the two factors referred to in the text, Professor Leflar's approach contains three other choice-influencing factors: (1) predictability of results; (2) maintenance of interstate and international order; and (3) simplification of the judicial task. Leflar, Conflicts Law: More on ChoiceInfluencing Considerations, 54 CALIF. L. REv. 1584, 1586-87 (1966).

34. See Allstate Ins. Co. v. Hague, 449 U.S. 302, 307, 319 (1981) (upholding Minnesota's selection of its own law on "better law" grounds and discussing Minnesota's interest in "full compensation for 'resident accident victims' to keep them 'off welfare rolls' and able 'to meet financial obligations'" (quoting Allstate Ins. Co. v. Hague, 289 N.W.2d 43, 49 (Minn. 1978))).

35. See Restatement of Conflict of LAws $\$ \S 377-379$ (1934). Prior to the revolution in choice of law during the 1950's and 1960's, the substantive law of the place of injury, lex loci delicti, universally governed the rights and liabilities of parties to a tort suit. 
would apply State A's negligence and unlimited recovery laws to the claims originally filed in State C.

Claims Brought Originally in State D: Professor Baxter's comparative impairment analysis attempts to resolve true conflicts by considering which of the interested states' policies would be impaired most by application of another state's law. ${ }^{38}$ The laws of States D and E differ only as to standards of liability. Considering that the purpose underlying a rule of strict liability may be twofold, ${ }^{37}$ a State $D$ court would probably hold that State D's policy in favor of facilitating recovery by tort victims against manufacturers would suffer more harm were its law not applied for the benefit of its residents than would State E's interest in protecting its resident corporations from excessive liability were its law rejected. ${ }^{38}$ Thus, the transferee court would apply State D's strict liability and limited recovery laws to the claims originally filed in State D. ${ }^{38}$

The following chart summarizes the findings of the transferee court:

TABLE II

\begin{tabular}{|c|c|c|c|}
\hline Plaintiffs* & State of Filing & Standard of Liability & Damages \\
\hline A & A & negligence & unlimited \\
\hline B & B & strict liability & unlimited \\
\hline $\mathrm{B}^{\prime}$ & A & negligence & unlimited \\
\hline $\mathrm{C}$ & C & negligence & unlimited \\
\hline$C^{\prime}$ & A & negligence & limited \\
\hline D & D & strict liability & limited \\
\hline $\mathrm{D}^{\prime}$ & A & negligence & limited \\
\hline
\end{tabular}

* $\mathrm{B}^{\prime}, \mathrm{C}^{\prime}$, and $\mathrm{D}^{\prime}$ denote, respectively, plaintiffs from States B, C, and D who initially filed in State A.

\section{B. Current Law Does Not Achieve Equity or Efficiency}

The common claims of victims of single-incident mass torts are increasingly resolved through some form of collective adjudication. ${ }^{40}$ In theory,

36. See Baxter, supra note 8.

37. A state may impose strict liability on tortfeasors both to deter harmful conduct and to facilitate recovery by tort victims.

38. Cf. Washington, D.C. Air Crash, 559 F. Supp. 333, 346-47, 351 (D.D.C. 1983) (noting, without finding controlling, Washington State's legislatively expressed interest in providing fair treatment and protection for its resident corporations).

39. Cf. Boston Air Crash, 399 F. Supp. 1106, 1114 (D. Mass. 1975) (Massachusetts' interest in deterring harmful conduct and limiting liability of defendant doing business within its borders "materially and substantially less than that of New Hampshire in adequately providing for survivors of its own resident decedents").

40. Single-incident mass torts produce claims that squarely fit the consolidation requirements of 28 U.S.C. $\$ 1407$ and are routinely collected in a single forum. The Supreme Court's decision in Phillips Petroleum Co. v. Shutts, 105 S. Ct. 2965 (1985), increases the likelihood that such claims will be brought as class actions, See Miller \& Crump, supra note 9; see also In re "Agent Orange" Prod. 
collective adjudication is more efficient because it minimizes the time and resources expended by courts, facilitates and expedites the settlement of claims, and avoids concurrent or sequential resolutions of claims arising from the same set of facts. ${ }^{41}$ Moreover, collective adjudication theoretically is more equitable because it avoids disparate recoveries by injured parties and inconsistent standards of conduct for tortfeasors ${ }^{42}$ reduces inequalities in bargaining power between plaintiffs and defendants, ${ }^{43}$ and lowers the risk that early claimants will deplete available compensation funds and cause an inequitable allocation of compensatory and punitive damages. ${ }^{44}$

In practice, however, as the hypothetical case illustrates, choice of law problems derail the equity and efficiency advantages that collective adjudi-

Liab. Litig., 100 F.R.D. 718, 720 (E.D.N.Y. 1983) (certifying FED. R. Crv. P. 23(b)(3) class action), mandamus denied sub nom. In re Diamond Shamrock Chems. Co., 725 F.2d 858 (2d. Cir.), cert. denied, 465 U.S. 1067 (1984); In re Federal Skywalk Cases, 95 F.R.D. 483, 486 (W.D. Mo. 1982) (granting FED. R. Crv. P. 23(b)(3) class certification regarding issues of compensatory damage liability, punitive damages liability, and amount of punitive damages); Coburn v. 4-R Corp., 77 F.R.D. 43 (E.D. Ky. 1977) (prosecution of individual actions following nightclub fire created risk of imposing inconsistent standards of conduct or of reducing limited fund in manner that would impair ability of subsequent plaintiffs to protect their interests), mandamus denied sub nom. Union Light, Heat \& Power Co. v. United States Dist. Court, 588 F.2d 543 (6th Cir. 1978), cert. dismissed, 443 U.S. 913 (1979); Hernandez v. Motor Vessel Skyward, 61 F.R.D. 558, 561 (S.D. Fla. 1973) (issue of liability for food poisoning on cruise ship certified under FED. R. Crv. P. 23(b)(1)(A) primarily to avoid inconsistent adjudications), aff'd mem., 507 F.2d 1278 (5th Cir. 1975); Gabel v. Hughes Air Corp., 350 F. Supp. 624 (C.D. Cal. 1972) (issue of liability in air crash certified under FED. R. Crv. P. $23(b)(1)(A)$ and $23(b)(1)(B)$ to avoid inconsistent adjudications and prevent impairment of plaintiffs' ability to protect their interests).

For proposals encouraging greater use of collective adjudication, see Rosenberg, The Causal Connection in Mass Exposure Cases: A "Public Law" Vision of the Tort System, 97 Harv. L. Rev. 851 (1984) (proposing class action treatment of mass exposure claims with causation and assignment of liability determined under proportionality rule); Note, Class Certification in Mass Accident Cases Under Rule 23(b)(I), 96 HARv. L. REv. 1143 (1983) [hereinafter Note, Class Certification in Mass Accident Cases]; Note, Class Actions for Punitive Damages, 81 Mrch. L. REv. 1787 (1983).

41. See, e.g., Miller \& Crump, supra note 9:

When many injuries are traceable to a single incident, almost all liability inquiries, including most questions of specific causation, are focused on an event that occurred at a definite time and place. As a result, gains in both efficiency and equity from group resolution may be greater than in other mass tort cases.

Id. at 44; see also Note, Class Certification in Mass Accident Cases, supra note 40, at 1144-46 (discussing efficiency gains from collective adjudication).

From a judicial perspective, efficiency frequently means collective adjudication of cases presenting common questions of law or fact. See FED. R. Civ. P. 23; see also 28 U.S.C. $\$ 1407$ (1982) (authorizing transfer for consolidated pre-trial proceedings of actions involving one or more common questions of fact); In re Air Crash Disaster Near New Orleans, La. on July 9, 1982, 548 F. Supp. 1268 (J.P.M.D.L. 1982) (citing promotion of just and efficient conduct of litigation as support for $\S 1407$ transfer). From a claimant's perspective, efficiency often means lower litigation costs through quick resolution by settlement or trial. For a mass tort litigant, such efficiencies may be realized through greater use of class actions and coordinated representation. Finally, the efficient result for society can be measured by whether and to what extent the legal system's resolution of an issue encourages behavior that will in the long run reduce the total costs of accidents to society. See generally G. Calabresi, The Costs of Accidents (1970).

42. See Paris Air Crash, 399 F. Supp. 732 (C.D. Cal. 1975) (discussed supra note 17 \& infra note 49 ).

43. See Note, Class Certification in Mass Accident Cases, supra note 40, at 1145.

44. Id. 
cation otherwise promises. The transferee court's obligation to discover what law some state other than the one in which it sits would find applicable requires considerable expenditure of judicial resources. ${ }^{45}$ Because varying state laws fragment claimants' initially common interests, such pre-trial choice of law rulings quickly dissipate the efficiency gains collective adjudication is intended to achieve. ${ }^{48}$ Further, the transferee court's choice of law rulings produce four distinct combinations of laws governing the claims of similarly situated parties. ${ }^{47}$ Thus, while claimants originally filing in State B can receive unlimited recovery under a strict liability standard, claimants from States C and D who originally filed in State A must prove fault on the part of the manufacturer to obtain even a limited recovery. ${ }^{48}$ The disparate effects of such rulings on the settlement values of otherwise identical claims of the plaintiffs contravene the intent of a legal system that strives to compensate the victims of mass torts fairly. ${ }^{49}$

\footnotetext{
45. As one district court judge has stated:

The law on "choice of law" in the various states and in the federal courts is a veritable jungle, which, if the law can be found out, leads not to a "rule of action" but a reign of chaos dominated in each case by the judge's "informed guess" as to what some other state than the one in which he sits would hold its law to be.
}

Paris Air Crash, 399 F. Supp. 732,739 (C.D. Cal. 1975).

46. Under current law, class certification by itself probably does not ensure uniformity with respect to either choice of law or substantive rules. See Agent Orange, 580 F. Supp. 690, 695 (E.D.N.Y. 1984) (Weinstein, C.J.) ("Certifying this as a class action with residents of different states as plaintiffs does not, we assume. . . reduce all disputes within the litigation to one subject to the substantive and conflicts of law rules of New York. . . Where relevant state substantive and conflicts rules are not uniform, certification does not, we will assume, provide uniformity."); see also infra note 101 (recent proposals for greater use of class actions acknowledge choice of law problems).

Judge Weinstein's assumptions have been confirmed in part by the Supreme Court's recent decision in Phillips Petroleum Co. v. Shutts, 105 S.Ct. 2965 (1985), where the Court reversed on due process grounds a Kansas court's application of Kansas' substantive law to all plaintiffs in a nationwide class action. The Court held that Kansas did not have sufficient contacts with the out-of-state claims to warrant the application of its law to all claims. The Court did not, however, suggest that uniform application of a single state's law would be impermissible where sufficient contacts were present.

47. In this way equity among like claimants is violated. Cf. Boston Air Crash, 399 F. Supp. 1106 (D. Mass. 1975). There the transferee district court found that the various forms of interest analysis-"significant contacts," "substantial contacts," "domicile of decedent," and "public policy"- of Vermont, New Hampshire, New York, and Florida, respectively, pointed to the substantive law of the state of domicile to govern the claims initially filed in each state. Together with the application of lex loci delicti to those claims originally filed in Massachusetts, the court's choice of law decisions effectively limited the damages recoverable by some of the crash victims without limiting the damages available to others. Id. at 1115; see also supra note 17 (discussing potential for inequitable result in Paris Air Crash).

48. Presiding over a similar situation, the district court judge in the Chicago Air Crash case commented:

It is unjust as well as ludicrous that such issues as the standard of liability (no-fault, compara-

tive negligence, contributory negligence), the measure of damages, [and] whether . . . damages

for pain and suffering are recoverable... should vary from case to case arising out of the same disaster depending on the vagaries of the applicable state law.

In re Air Crash Disaster Near Chicago, Ill. on May 25, 1979, 526 F. Supp. 226, 233 (N.D. Ill. 1981).

49. Thus, current choice of law decisionmaking does not achieve equitable results for mass tort victims as a group.

Society's desire to compensate tort victims fairly and adequately can be seen in several recent legal 
Equal treatment of similar claims is a fundamental principle of American law. ${ }^{80}$ Counterbalancing this principle of equality is the delegation of substantial lawmaking authority to the individual states within our federal system. $^{\text {s1 }}$ Because states have different laws on many issues, a litigant suing in one state may often recover while his counterpart suing in a neighboring state on a similar transaction does not. It is one thing to contemplate the disparate ways different state laws may resolve a given dispute; it is quite another to accept such disparities in the context of a mass tort suit consolidated in a single forum adjudicating, for example, the identical claims of passengers sitting side by side aboard an airplane. ${ }^{\mathbf{} 2}$ Unlike the victims of single-incident mass torts, non-mass tort victims do not share all the characteristics that largely determine which legal rules will apply to their claims. ${ }^{83}$ Nor does the adjudication of their claims trigger the federal interest raised by multistate mass torts. ${ }^{54}$ On the other

developments. The movement in tort law toward unrestricted recovery has led to the relative disuse of such anti-recovery doctrines as assumption of risk and contributory negligence as complete bars to recovery and to the expansion of strict liability across a range of issues in products liability. See, e.g., Greenman v. Yuba Power Prods., Inc., 59 Cal. 2d 57, 62-63, 377 P.2d 897, 900, 27 Cal. Rptr. 697, 700 (1962) (listing expanding range of products that carry strict liability).

The arguments for unlimited compensation carry even greater weight in the context of mass torts. The victims of mass accidents ordinarily have no control over what happens to them and thus cannot be said to possess the responsibility traits upon which rules that limit or wholly deny recovery partially rely:

The decedents bought a ticket, got on a plane, and were killed. Not only did they have nothing

to do with the relationships between the defendants, but they had no way of finding them out

or learning of any acts or efforts of defendants to correct or prevent defects in the plane or its parts, or not to do so.

In re Paris Air Crash of March 3, 1974, 69 F.R.D. 310, 321 (C.D. Cal. 1975). In recent years, Congress has addressed the issue of compensation for victims of certain mass accidents. See, e.g., Price-Anderson Act, 42 U.S.C. $\$ 2210$ (1982) (establishing $\$ 560$ million aggregate liability for single nuclear incident resulting from operation of federally licensed private nuclear power plant). In response to critics of the Price-Anderson Act's limitation on aggregate liability, Professor Arthur Murphy has argued that the Act, though limiting liability, has at least ensured the availability of some amount of compensation funds that private insurers would otherwise be reluctant to provide. See N.Y. Times, Jan. 31,1986 at A30, col. 3.

50. See Pope \& Talbot, Inc. v. Hawn, 346 U.S. 406, 410 (1953) (Erie was "designed to ensure that litigants with the same kind of case would have their rights measured by the same legal standards of liability").

51. U.S. Const, amend. X. provides, "The powers not delegated to the United States by the Constitution, nor prohibited by it to the States, are reserved to the States respectively . . .."

52. See In re "Agent Orange" Prod. Liab. Litig., 635 F.2d 987, 999 (2d Cir. 1980) (Feinberg, C.J., dissenting) ("If state law is applied in the present litigation . . . then veterans may well be subjected to sharply differing rules of law in the pursuit of their remedies . . . [and their] recoveries for Agent Orange injuries will vary widely."); Friendly, In Praise of Erie-And of the New Federal Common Law, 39 N.Y.U. L. REv. 383, 417-18 (1964) (criticizing application of different state laws to mass tort suits as producing "seeming injustice that the estate of one passenger might recover without limit whereas that of the man sitting next to him could get only a small sum").

53. Although mass tort victims also are not alike in all respects-e.g., they may be from different states-the characteristics to which the text refers are the individual tort victim's active traits that a court would consider to resolve a question of contributory negligence or causation. These so-called active traits would, by definition, see supra note 1 , be the same for single-incident, multistate mass tort victims. Cf. supra note 49 (mass tort victims have little control over accident causing injury).

54. See infra notes $83-86$ and accompanying text. 
hand, the inherently interstate nature of the accidents that harm mass tort victims and the commonality of the victims' factual claims both raise an interest in, and permit the realization of, unified recovery standards. Thus, society's interest and the interests of individual victims in the integrity of mass tort adjudication require that the principles of equity advanced in this Note override competing values of federalism in mass tort litigation. ${ }^{.5}$

\section{Congress' Role in Removing the Choice of Law Impasse}

Lower federal courts face two major obstacles to fair and efficient choice of law decisionmaking in mass tort litigation: a mélange of biased and rigid state choice of law rules ${ }^{58}$ and Supreme Court decisions that compel application of those rules in diversity suits. ${ }^{57}$ The present situation is unlikely to change without congressional action.

\section{A. A Judicial Solution is Unlikely}

\section{State Choice of Law Doctrine}

Analysis of state choice of law rules incorporating the modern approach $^{\mathbf{6 8}}$ reveals why those rules are unlikely to produce equity and efficiency in mass tort litigation. First, as the example in Section I demonstrates, the heavy emphasis that interest analysis places on domicile requires a federal court presiding over a mass tort suit to consider the substantive laws of several states. ${ }^{59}$ Because state laws often vary, this requirement virtually ensures that different laws will govern similar claims. In addition, the greater the number of states represented by the claimants,

55. Cf. Miller \& Crump, supra note 9, at 71 (federalism benefits of non-collective adjudication "hardly would be worthwhile" if there is risk of insufficient or no recovery by injured parties).

56. Twenty-nine states use one or more of six modern choice rules, while 16 states adhere to the traditional lex loci delicti. See Kay, Theory into Practice: Choice of Law in the Courts, 34 MERCER L. REv. 521 (1983). In this exhaustive survey of state choice rules, Professor Kay records with some skepticism the energetic, yet slightly muddled, adoption of modern choice formulas by a number of states and the surprising tenacity with which a considerable number of states have resisted change.

57. Van Dusen v. Barrack, 376 U.S. 612 (1964); Klaxon Co. v. Stentor Elec. Mfg. Co., 313 U.S. 487 (1941).

58. The focus in this section is on interest analysis. The rule of lex loci delicti certainly forecloses biases in favor of both domicile and forum law. Thus, if all states adhered to the traditional rule, many of the choice of law problems federal courts face in mass accident litigation would be eliminated, albeit at the cost of any overall strategy to improve mass tort adjudication. The legal system can, and should be encouraged to, do better. The crux of the choice of law dilemma in mass tort suits is the mix of choice rules applied, not the difficulty of the principled inquiry some modern rules require. A choice of law solution for mass tort suits should not retreat to the traditional rule; rather, it should incorporate in workable form some of the insights modern choice methods have advanced.

59. See supra notes 17-39 and accompanying text. 
the more unmanageable will be the court's task in organizing and following numerous different bodies of complex substantive principles. ${ }^{60}$

Second, the tendency of state courts to favor forum law reinforces the emphasis that interest analysis places on domicile. Professor Currie felt-with some resignation-that the selection of forum law is the inevitable resolution of true conflicts. ${ }^{61}$ Modifications of Professor Currie's approach have failed to offset the bias toward forum law. ${ }^{62}$ Under the "comparative impairment" approach, the court hearing the case can more easily assess, and hence is more sympathetic to, the detrimental effects to its state's sovereignty should its law be ignored than the harm to another state if the latter's law is rejected. "S Similarly, under the "better law" component of Professor Leflar's choice-influencing-factors approach, a state court is naturally inclined to feel that its law is the better one. ${ }^{64}$

\section{Federal Choice of Law Doctrine}

Although its decision in Klaxon Co. v. Stentor Electric Manufacturing $\mathrm{Co}^{6 \mathrm{~B}}$ has received much scholarly criticism, ${ }^{6 B}$ the Supreme Court recently reiterated the obligation of federal courts to follow the choice of law rules of the states in which they sit. ${ }^{67}$ As in Klaxon, the Court's narrow focus

60. Cf. Miller \& Crump, supra note 9, at 64 (discussing court's heavy burden in 50-state action).

61. See Currie, supra note 28, at 1242-43 (containing Currie's advice for resolution of true conflicts):

$\S 4$. If, upon reconsideration, the court finds that a conflict between the legitimate interests of two states is unavoidable, it should apply the law of the forum.

$\S 5$. If the forum is disinterested, but an unavoidable conflict exists between the laws of the two other states, . . . it should apply the law of the forum-until someone comes along with a Id. better idea.

62. In addition to the modern approaches discussed in the text, other variations on interest analysis include Professor Ehrenzweig's lex fori approach. See Ehrenzweig, The Lex Fori-Basic Rule in the Conflict of Laws, $58 \mathrm{MrCH}$. L. REv. 637 (1960) (offsetting strong presumption for forum law with preference for strict use of forum non conveniens dismissals); see also von Mehren, Recent Trends in Choice of Law Methodology, 60 CoRnell L. Rev. 927 (1975) (advocating principled weighing of conflicting policies).

63. See, e.g., Bernhard v. Harrah's Club, 16 Cal. 3d 313, 320, 546 P.2d 719, 723, 128 Cal. Rptr. 215, 219 (1976) (California's interests would be more impaired if Nevada law were applied than would be Nevada's if California law were applied); see also Note, Choice of Law for True Conflicts, 65 CAlif. L. Rev. 290, 303 (1977) (courts of different states will arrive at different judgments about the relative degree of impairment to their external objectives in close cases).

64. See Allstate Ins. Co. v. Hague, 449 U.S. 302 (1981) (discussed supra note 34 \& infra note 71); Milkovich v. Saari, 295 Minn. 155, 171, 203 N.W.2d 408, 417 (1973) (Minnesota's common law rule of liability superior to Canada's guest statute and thus applicable even where both litigants from Canada); E. Scoles \& P. HAY, supra note 8, at 31 (several states now follow "better law" approach, "almost invariably with the result that the "better law' [is] found to be that of the forum"); Brilmayer, Legitimale Interests in Multistate Problems: As Between State and Federal Law, 79 MrCH. L. Rev. $1315,1326 \mathrm{n} .55$ (1983) (better law "almost invariably turns out to be the forum's own rule of decision").

65. 313 U.S. 487 (1941).

66. See supra note 8 .

67. Day \& Zimmermann, Inc. v. Challoner, 423 U.S. 3 (1975). 
in Day $\mathcal{E}^{\circ}$ Zimmermann, Inc. v. Challoner ${ }^{88}$ underscores its apparent acceptance of the limitations that state choice of law rules place on a federal court's ability to make equitable and efficient choice of law decisions in a multidistrict mass tort case. ${ }^{69}$ Beyond Klaxon, moreover, the Court's ruling in Allstate Insurance Co. v. Hague ${ }^{70}$ that there exist few constitutional limitations on a state court's choice of law decision ${ }^{71}$ has the indirect effect of affirming a solicitude for local policies and interests that is antithetical to the goals sought in mass tort adjudication.

Even if, however, the Court were today presented with an opportunity to overrule Klaxon, and did so, choice of law decisionmaking problems in mass tort litigation would persist. Given that choice of law rules are primarily the product of state common law, the Court would be reluctant to go beyond a mere reversal of Klaxon and, in effect, preempt an area of state law by issuing a set of choice of law guidelines for the lower federal courts. Furthermore, the choice of law principles proposed by this Note indirectly address the question of appropriate remedies under tort law, which, like choice of law, is an area of law into which the Court rarely ventures. The policy considerations of such implicit involvement in tort law suggest that Congress is a more appropriate federal body to effect comprehensive change.

\section{B. A Congressional Solution}

Whether Congress has the authority to intervene in this matter is apparent from both the text of the Constitution ${ }^{72}$ and recent congressional

68. 423 U.S. 3 (1975).

69. As discussed above, see supra note 11, the Court's reaffirmance of Klaxon in Day \& Zimmerman rejected a federal court's innovative attempt to elude an overly restrictive state choice of law rule.

70. 449 U.S. 302 (1981) (plurality opinion per Brennan, J.).

71. In Hague, the plurality's insistence that a "significant aggregation" of contacts was necessary to create a constitutionally sufficient interest for a state to apply its own law was somewhat discredited by the transparency of the Minnesota contacts the Court deemed significant. See Brilmayer, supra note 64, at 1318-19. For a discussion of the minimal constitutional limitations that do exist, see John Hancock Mut. Life Ins. Co. v. Yates, 299 U.S. 178 (1936) (postoccurrence change of residence to forum state alone inadequate to support choice of law decision); Home Ins. Co. v. Dick, 281 U.S. 397 (1930) (nominal residence alone inadequate to support choice of law decision); $c f$. Phillips Petroleum Co. v. Shutts, 105 S. Ct. 2965 (1985) (rejecting forum state's application of its own law to out-of-state claims in class action suit where $97 \%$ of plaintiff-class members were non-residents and $99 \%$ of the gas leases in dispute were also out-of-state).

Professors Miller and Crump suggest that the constitutional limits in the Court's recent choice of law decisions in Shutts and Allstate should be interpreted "to limit unreasonable forum shopping and preserve parties' expectations." Miller \& Crump, supra note 9, at 62. The choice of law principles set forth in this Note's proposed statute, infra Section IV (tortfeasor's reasonable expectations one of three principal factors in choice of law decision), accord with this interpretation of the constitutional parameters of choice of law decisions.

72. The analysis in the text relies primarily on the affirmative grant to Congress under the full faith and credit clause. See also Miller \& Crump, supra note 9, at 78 (expressing "little doubt that congressional power to enact a choice of law rule exists under the diversity jurisdiction, due process, privileges and immunities, commerce, equal protection, and full faith and credit clauses of the 
action. The second sentence of the Constitution's full faith and credit clause $^{73}$ grants Congress exclusive authority to prescribe the manner in which extraterritorial effect is to be given to the "Acts, Records, and [judicial] Proceedings" of the states. ${ }^{74}$ The general implementing statute passed by the first Congress prescribes that the full faith and credit due a state's acts, records and proceedings is the same as that which "they have by law or usage in the courts of ... [the rendering] State."75 While "full faith and credit" has proved to be an intelligible standard for the effect to be given to records and judgments that have unambiguous application, its insufficiency as an analytical basis for choice of law decisions-which require a balancing of competing state laws of presumptively equal weight-has led courts to ignore its effect in the conflicts context and to enforce its prescription only as to records and judgments. ${ }^{76}$

\section{Constitution").}

This Note suggests a structural analysis to elicit the constitutional policies congressional involvement would serve. The Constitution endows all citizens with the right to travel and conduct commerce freely across state lines. An unfortunate consequence of freedom of mobility in modern technological society is the recurring phenomenon of mass torts. It is well settled that the commerce and equal protection clauses empower Congress to enact legislation ameliorating the inequities that varying state laws may impose on those involved in interstate commerce. See, e.g., Federal Employers' Liability Act, 45 U.S.C. $\$ \$ 51-60$ (1982). In this regard, there are few, if any, substantive restraints on Congress' power under the commerce clause. Garcia v. San Antonio Metro. Transit Auth., 469 U.S. 528 (1985).

A statutory solution designed to enhance the judicial system's ability to administer personal injury and wrongful death claims arising from tortious behavior inextricably connected to interstate commerce is therefore an appropriate, albeit novel, exercise of Congress' power to address inherently interstate problems within our federal system.

73. U.S. Const. art. IV, $\S 1$ provides: "Full Faith and Credit shall be given in each State to the public Acts, Records, and judicial Proceedings of every other State. And the Congress may by general Laws prescribe the Manner in which such Acts, Records and Proceedings shall be proved, and the Effect thercof."

74. The proposition that the full faith and credit clause empowers Congress to establish choice of law rules is widely accepted. See, e.g., C. WRIGHT, supra note 8, at 366 (full faith and credit clause an affirmative grant of authority to Congress to create uniform body of conflicts principles); Baxter, supra note 8, at 22-42; Whitten, The Constitutional Limitations on State Choice of Law: Full Faith and Credit, 12 MEM. ST. U.L. REv. 1, 62-63, 66-69 (1981) (Congress given exclusive authority under full faith and credit clause to establish nationwide choice of law rules for states); see also Cheatham, Federal Control of Conflict of Laws, 6 VAND. L. REV. 581, 585, 600 (1953) (federal control over conflict of laws explicit in full faith and credit clause); Cook, The Powers of Congress Under the Full Faith and Credit Clause, 28 YALE L.J. 421, 422-26 (1919) (discussing range of Congress' power over conflict of laws); Jackson, Full Faith and Credit-The Lawyer's Clause of the Constitution, 45 Colum. L. Rev. 1, 21-24 (1945) (same).

75. 28 U.S.C. § 1738 (1982).

76. The statute proposed in this Note would require congressional involvement in the process by which extraterritorial effect is to be given to state laws. In this regard, constitutional scholars once disagreed as to whether the Framers intended the word "Acts" to include state decisional as well as statutory law. For two reasons, the ambiguity today appears to have been resolved in favor of an interpretation that places state common law rules within the compass of the word "Acts." First, Erie R.R. v. Tompkins, 304 U.S. 64, 78 (1938) ("whether the law of the State shall be declared by its Legislature in a statute or by its highest court in a decision is not a matter of federal concern"), disfavors an interpretation that would distinguish between statutory and decisional law, to the exclusion of the latter. Jackson, supra note 74 , at 12 . Second, the importance of state courts as coequal in their lawmaking authority to state legislatures favors an interpretation that accords equal weight to 
The Parental Kidnapping Prevention Act of $1980^{77}$ (PKPA) is a recent example of congressional action under the full faith and credit clause to enact a national standard where a compelling federal interest is present. The statute was enacted to eliminate the harm to children caused by "child-snatching" by requiring states to give full faith and credit to the custody decrees of another jurisdiction. ${ }^{78}$ Like its predecessor, the Uniform Child Custody Jurisdiction Act of 1968, ${ }^{79}$ the PKPA was adopted to remedy the chaos in interstate custody litigation caused by the Supreme Court's failure to mandate the application of the full faith and credit clause to the custody decrees of sister states. ${ }^{80}$ The statute contains a set of uniform principles under which questions regarding the jurisdiction of a court first issuing a decree, and thus by implication its choice of law, are to be resolved. ${ }^{81}$

The PKPA resolves the full faith and credit issue explicitly by reference to the validity of the jurisdiction of the rendering court. Because the rendering court ordinarily would apply forum law in child custody decree cases, however, the jurisdictional inquiry is equivalent to review of that court's choice of law. ${ }^{82}$ Designed to address an interstate problem that the application of state choice of law rules would only exacerbate, the PKPA can be viewed as a recent precedent firmly establishing Congress' ability to legislate in the area of choice of law by issuing a set of uniform standards to be followed in state courts.

Congress should exercise its power where there is a demonstrable need

the efforts of both. See generally Magnolia Petroleum Co. v. Hunt, 320 U.S. 430, 436 (1943) (referring to full "faith and credit ... to which local common and statutory law is entitled under the Constitution and laws of the United States" (emphasis added)); Cheatham, supra note 74, at 602-03 (no difference in most states between statutory law and common law concerning full faith and credit clause); Whitten, supra note 74, at 66-68 (decisions of modern state judges sufficiently analogous to legislation to include decisional law within meaning of "acts," original meaning notwithstanding).

77. 28 U.S.C. $\$ 1738$ A (1982).

78. For a concise explanation of the jurisdictional and choice of law aspects of child-snatching, see Brilmayer, Credit Due Judgments and Credit Due Laws: The Respective Roles of Due Process and Full Faith and Credit in the Interstate Context, 70 IowA L. REv. 95, 102-03 (1984).

79. Unif. Child Custody JuRisdiction ACt, 9 U.L.A. 111 (1979).

80. See, e.g., Ford v. Ford, 371 U.S. 187 (1962); Kovacs v. Brewer, 356 U.S. 604 (1958); see also Child Custody Clearinghouse and Information Exchange, Interstate and InternaTional Ghild Custody Disputes 10 (4th ed. 1984) (Uniform Child Custody Jurisdiction Act designed to fill gap left by Supreme Court decisions).

81. See Flannery v. Stephenson, 416 So. 2d 1034 (Ala. Civ. App. 1982). These guidelines direct a court to consider such factors as the residence of the child on the date of the commencement of the initial proceeding, 28 U.S.C. $\$ 1738 \mathrm{~A}(\mathrm{c})(2)(\mathrm{A})(\mathrm{i})$ (1982), evidence of mistreatment or abuse of the child, id. at $\$ 1738 \mathrm{~A}(\mathrm{c})(2)(\mathrm{C})(\mathrm{ii})$, and the extent to which the best interest of the child was served by the assumption of jurisdiction by the court first issuing the decree, id. at $\S 1738 \mathrm{~A}(\mathrm{c})(2)(\mathrm{D})(\mathrm{ii})$.

82. See Weinberg, Choice of Law and Minimal Scrutiny, 49 U. Chr. L. REv. 440, 465 n.131 (1982) (discussing PKPA as determining choice of law); see also Averill, Choice-of-Law Problems Raised by Sister State Judgments and the Full-Faith-and-Credit Mandate, 64 Nw. U.L. REv. 686 (1969) (analyzing relationship between choice of law and concept of full faith and credit between sister state judgments). 
in the federal system to provide national solutions to inherently interstate problems. ${ }^{83}$ Choice of law decisions in mass tort cases constitute an inherently federal problem for two reasons. First, most mass torts arise from interstate economic activity and directly affect citizens from many states. Second, the usefulness and availability of procedural devices created by federal law ${ }^{84}$ have led litigants to rely almost exclusively upon federal courts for the adjudication of mass tort claims. ${ }^{85}$ Particularly because the nature of the problem requires something more than a narrowly drawn judicial opinion, Congress is the proper source of federal standards. ${ }^{86}$

\section{A Statutory Solution}

To remedy the choice of law problems described in Section I, Congress should enact a law providing:

Whenever state law supplies the rule of decision on an issue in litigation arising from a mass tort, ${ }^{87}$ the federal court shall make its

83. Judge Friendly has written:

For Congress to direct a federal court sitting in State A whether to apply the internal law of State A, B or C, or to use its own judgment which to apply, can well be said to be 'necessary and proper' to enabling federal judges to function, and consistent with the general role of the central government under the Constitution, in a way that prescription of a code of substantive law to supplant the otherwise applicable law of a state is not.

Friendly, supra note 52, at 402 (citation omitted). It is important to emphasize that by limiting Congress' role to enacting an essentially procedural rule, see Miller \& Crump, supra note 9, at 78 n.534 (choice of law rules fairly characterized as procedural), this Note's proposed statute, infra Section IV, does not encroach upon the states' authority to develop substantive bodies of tort law. The favorable law preference of this Note's proposal does not invalidate this distinction. Procedural rules commonly affect substantive results and include implicit value judgments.

84. See Miller \& Crump, supra note 9, at 67, 70 (discussing federal courts' superior ability to handle complex, multidistrict litigation); FED. R. Crv. P. 19, 20 (joinder), 23 (class actions), 24 (intervention), 42 (consolidation); see also supra notes 22-23 (discussing federal transfer and consolidation statutes). Following a $\S 1404$ transfer of all cases to itself for all purposes, a transferee court may then use Rule 42(a) to consolidate the actions for a single trial. See, e.g., In re Multidistrict Civil Actions Involving the Air Crash Disaster Near Hanover, N.H. on Oct. 25, 1968, 342 F. Supp. 907, 908 (D.N.H. 1971).

85. For this reason, one could also argue that when presiding over multidistrict mass tort litigation, the lower federal courts no longer exercise jurisdiction coextensive with state courts. Thus, the basic rationale beneath Erie and Klaxon may no longer hold true. There have been proposals to prevent the application of Klaxon in situations where the federal court exercises jurisdiction beyond that of the state in which it sits. See infra note 86.

86. See, e.g., Miller \& Crump, supra note 9, at 78 \& n.534 (discussing how choice of law rules might be governed by federal statute); see also AMERICAN LAW INSTITUTE, STUDY OF THE Division of JuRISDiction BetweEn STATE AND Federal Courts 73, 402-04 (1969) (proposing statute that would abrogate Klaxon where non-resident parties have been served pursuant to proposed dispersed necessary parties rule); H.R. 4159, 98th Cong., 1st Sess. (1983) (proposal of Rep. Kastenmeier to amend Judicial Code to permit cases of multidistrict litigation to be consolidated for purposes of determining liability, including proposal to permit transferee court to determine source of substantive law).

87. No attempt has been made here to define precisely various terms-e.g., "mass tort," "rule of decision," and "parties similarly situated"-that will determine the statute's application in any particular case. For a general description of the kinds of mass torts this proposal is intended to reach, see supra note 1 . The principal criteria that will operate once the statute has been invoked are discussed 
own decision as to which state's law shall govern the rights and liabilities of all parties similarly situated; in deciding this question, the court shall: i) consider the laws of only those states with contacts to the mass tort such that a defendant could reasonably have foreseen it would be subject to those laws; ii) select from among the laws available the one most favorable to the plaintiffs; and iii) apply the same law to the claims of similarly situated parties.

Analysis of the three primary features of the proposed statute demonstrates the ways in which the statute would promote equitable and efficient mass tort adjudication.

\section{A. A Reasonable Expectations Standard}

In Allstate Insurance Co. v. Hague, ${ }^{88}$ a plurality of the Court observed that selection of a state's law comports with due process when it is neither "arbitrary nor fundamentally unfair."89 It is arguable that the Court's finding that this standard was satisfied in Hague was based on an affirmance of the forum- and domicile-oriented policies characteristic of modern choice of law rules. ${ }^{90}$ The hypothetical case in Section II, however, revealed how fidelity to forum and domicile interests contravenes the equity and efficiency objectives of mass tort adjudication. ${ }^{21}$ The proposed statute therefore requires identification of available state laws based upon

infra notes 88-105 and accompanying text.

88. 449 U.S. 302 (1981).

89. Id. at 313 (opinion of Brennan, J.).

90. Id. at 338 (Powell, J., dissenting) (criticizing plurality's emphasis on "presence of the plaintiff and the fact that the deceased worked in the forum State").

91. See supra notes 17-49 and accompanying text. The heavy emphasis that interest analysis places on domicile is not, however, entirely misplaced or illogical. A state's interest in issues of liability and measure of damages, which directly affect the welfare of its citizens, is manifest. Offsetting this state interest, however, is the federal interest in achieving equity and efficiency in the adjudication of mass tort claims. Two strains of thought suggest that subordinating state interests to federal interests is acceptable for choice of law decisionmaking in mass tort litigation. First, the discussion of contemporary choice of law doctrine, supra notes 28-39 and accompanying text, demonstrates that state sovereignty is not significantly harmed by such a result. By definition, the resolution of any "true conflict," through either the traditional or a modern approach, subordinates one state's legitimate interest in having its law applied. Further, contemporary solutions to true conflicts-for example, forum law (Currie), see supra note 31, or the "better law" (Leflar), see supra notes 33-34-are not meaningfully attentive to any state's interest. See Chicago Air Crash, 644 F.2d 594, 630 (7th Cir. 1981) (selecting law of less interested forum where "interested" states' laws conflicted).

A second state sovereignty issue concerns the role of the federal court in making the choice of law decision in the first place; that is, while it may be permissible for the states to override each other's interests, it may be improper for federal courts to trump state interests. The discussion of federal authority in the choice of law field under full faith and credit, supra notes 72-82 and accompanying text, addresses this issue and concludes that the requisite federal authority and justification exist. For a discussion of the jurisdictional aspects of this issue, see Brilmayer \& Lee, State Sovereignty and the Two Faces of Federalism: A Comparative Study of Federal Jurisdiction and the Conflict of Laws, 60 Notre Dame L. Rev. 833, 860 (1985) (analyzing Supreme Court's "misconceived insistence that federal and state courts are virtually interchangeable"). 
the defendant's reasonable expectations regarding the laws that might govern its conduct. ${ }^{22}$

A reasonable expectations standard serves a number of equity and efficiency goals. Narrowing the range of substantive rules for consideration reduces the time and resources required of a court making choice of law decisions in a mass tort suit. By greatly increasing the predictability of the applicable law, this prescription both facilitates the settlement of claims and encourages defendants to insure themselves adequately against losses that could conceivably arise under the laws of states affected by their activities. Preparation by defendants for risk of loss furthers the compensation and loss-spreading policies of tort law and thus benefits both defendants and plaintiffs. Finally, subjecting defendants to only those laws they might reasonably have expected would govern their conduct better comports with the due process standards required of choice of law decisions. ${ }^{93}$

\section{B. The Law Most Favorable to Plaintiffs}

A principle common to most contemporary choice of law methods states that choice of law decisions should further the policies underlying a particular field of law. ${ }^{94}$ Insofar as two primary policy objectives of modern tort law are deterrence and compensation, ${ }^{95}$ a rule requiring selection of the law most favorable to the victims of mass torts is consistent with this well-established norm. ${ }^{96}$ The need for swift and sure compensation is

92. Under the proposed statute's reasonable expectations standard, the transferee court in this Note's hypothetical case, supra notes 17-39 and accompanying text, would have considered the laws of States B, C, and E. The defendant manufacturer could reasonably have foreseen that accidents involving the use of its planes might occur in the states of departure (B) and destination (C). See Washington, D.C. Air Crash, 559 F. Supp. 333, 338 (D.D.C. 1983) (manufacturer "had to foresee that its small, short-haul 737 aircraft would be used for departures from Washington National Airport"). Further, a corporate manufacturer would always expect to be subject to the substantive laws of the states where it is incorporated (E), maintains its principal place of business (E), and manufactures its product (B).

93. The "reasonable expectations" standard of personal jurisdiction doctrine, see World-Wide Volkswagen Corp. v. Woodson, 444 U.S. 286 (1980), has not been incorporated in the Court's choice of law decisions. Compare Allstate Ins. Co. v. Hague, 449 U.S. 302 (1981) (plurality opinion) (due process requires fundamental fairness) with id. at 337 (Powell, J., dissenting) (defendant's expectations are a measure of fundamental fairness). At least one commentator has noted the irony, or illogic, in the Court's position. See Silberman, Shaffer v. Heitner: The End of an Era, 53 N.Y.U. L. REv. 33,88 (1978) ("To believe that a defendant's contacts with the forum state should be stronger under the due process clause for jurisdictional purposes than for choice of law is to believe that an accused is more concerned with where he will be hanged than whether.").

94. See Restatement (SECOND) of Conflict of Laws $\$ 6(2)(e)(1971)$ (among factors relevant to choice of law are "basic policies underlying the particular field of law").

95. See supra note 49 and accompanying text.

96. Several commentators on choice of law have argued for selection of the law most favorable to the plaintiff. See, e.g., R. Weintraub, Commentary on the Conflict of Laws $\S 6.32$ (3d ed. 1986) (proposing tort choice of law rules that favor plaintiffs unless state with favorable law "does not have sufficient contact with the defendant or the defendant's actual or intended course of conduct to make application of its law unreasonable"); Kühne, Choice of Law in Products Liability, 60 CALIF. L. REv. 1, 32 (1972) (apply law favorable to plaintiff). 
particularly urgent for mass accident victims who, because of the unpredictability and potentially catastrophic consequences of such disasters, may be severely disadvantaged by long-delayed or inadequate recoveries. ${ }^{97}$

In less obvious ways, a choice of law rule requiring selection of the law most favorable to plaintiffs enhances the efficiency of a judicial response to mass disasters as well. Successful collective adjudication requires the maintenance of an identity of interests among those with similar claims. The knowledge that their claims will be governed by the most favorable of available laws removes incentives for individual litigants to opt out and pursue their claims individually. ${ }^{98}$ Thus, by crystallizing the common interests of mass accident victims, the proposed statute's most-favorable-law prescription leads to the realization of the efficiencies offered by collective adjudication.

\section{A Single Law for Like Claims}

The directive that a court apply the same rule of law to the claims of similarly situated parties releases federal courts from their obligation under current law to follow the choice of law rules of the states in which they sit. ${ }^{99}$ The judicial economies to be gained from permitting a federal court presiding over mass tort litigation to sidestep the morass of ambiguous, biased, and conflicting state choice of law rules are manifest. ${ }^{100}$ More important, by ensuring that cases involving common questions of fact raise common questions of law, the proposed statute removes a powerful deterrent to the increased use of the various procedures for collective adjudication available under current law. ${ }^{101}$ In this way, the statute encourages

97. See In re Paris Air Crash of March 3, 1974, 69 F.R.D. 310 (1975) (discussed supra note 49).

98. See supra note 41 and accompanying text (discussing efficiencies from collective adjudication). For a discussion of potentially conflicting interests of plaintiffs with large claims, see Note, Class Certification in Mass Accident Cases, supra note 40, at 1147-49 (acknowledging substantial and legitimate interests of those with large claims, author concludes that only way to achieve optimal balance among all competing interests is through procedure that binds all plaintiffs in joint action).

99. Van Dusen v. Barrack, 376 U.S. 612 (1964); Klaxon Co. v. Stentor Elec. Mfg. Co., 313 U.S. 487 (1941).

100. See Chicago Air Crash, 644 F.2d 594, 630-31 (7th Cir. 1981) (court unable to determine choice of law rule of Hawaii); Melville v. American Home Assurance Co., 443 F. Supp. 1064, 1107 (E.D. Pa. 1977) ("It is difficult enough to apply a state's choice of law methodology rationally and faithfully; it is confusion compounded when it is not initially clear which methodology is appropriate."); see also Paris Air Crash, 399 F. Supp. 732, 739 (C.D. Cal. 1975) (district court's choice of law dilemma discussed supra note 17 and accompanying text).

101. Several collective adjudication procedures provided for in the Federal Rules of Civil Procedure require common questions of law or fact. See, e.g., FED. R. Civ. P. 20(a) ("All persons may join in one action as plaintiffs if they assert any right to relief . . . in respect of or arising out of the same transaction, [or] occurrence . . . and if any question of law or fact common to all these persons will arise in the action."); id. 23(a)(2) ("One or more members of a class may sue . . . on behalf of all only if [inter alia] ... there are questions of law or fact common to the class . . ."); id. 42(a) ("When actions involving a common question of law or fact are pending before the court, it may order a joint hearing or trial of any or all the matters in issue in the actions . . . "). Choice of law 
efficiency for the judicial system, for litigants, and for society through the collective adjudication of common claims arising from a single set of facts. ${ }^{102}$

Selection of a single substantive standard serves equity considerations as well. By reducing the ex ante probability that a defendant will be subject to different standards of liability, ${ }^{103}$ the statute minimizes uncertainty in the articulation of standards of conduct for mass tortfeasors. ${ }^{104}$ By eliminating the ex post application of more than one substantive standard, it also avoids inconsistency in the burdens those with identical claims must meet in order to recover. Finally, the collective adjudication encouraged by the statute's "same law" prescription avoids the threat that individualized adjudication under diverse laws poses to the equitable allocation of potentially limited compensation funds. ${ }^{105}$

\section{Conclusion}

This Note seeks to stimulate a reappraisal of choice of law doctrine at the state and federal levels in light of the singularly multistate features of mass tort litigation. To restrict a federal court to the choice of law rules of a state court system infrequently, if ever, called upon to make choice of law decisions of such magnitude and complexity amounts to an inversion

problems are frequently cited as impediments to the use of these procedures. See, e.g., Causey v. Pan Am. World Airways, Inc., 66 F.R.D. 392, 397 (E.D. Va. 1975) (class action inappropriate for mass accident cases where plaintiffs reside in different jurisdictions).

For recognition that choice of law problems pose serious obstacles to collective adjudication, see Rosenberg, supra note 40, at $907 \mathrm{n} .222$ ("difficult choice of law . . questions may restrict the geographic and temporal scope of class actions and thus arbitrarily segregate class members"); Note, Jurisdiction over Unnamed Plaintiffs in Multistate Class Actions, 73 CAl.IF. L. REv. 181, 207-08 (1985) ("adjudication in one forum of all claims arising out of the same occurrence may be inefficient where choice-of-law problems arise"); Note, Class Certification in Mass Accident Cases, supra note 40, at 1146 ("joint litigation would be inappropriate if individual claims were governed by numerous, widely varying state laws"); Note, Class Actions for Punitive Damages, supra note 40, at 1804 (choice of law questions may force court to "exclude from the class those claimants who cannot recover punitive damages under applicable state law").

102. See Note, Class Certification in Mass Accident Cases, supra note 40, at 1144-46; see also note 41 and accompanying text (discussing efficiency gains of collective adjudication).

103. See supra note 18 and accompanying text (differing liability standards as to defective instructional manuals); see also Reyno v. Piper Aircraft Co., 630 F.2d 149, 171 n.95 (3d Cir. 1980) (discussing different standards of proof as to strict products liability between Ohio ("unreasonably dangerous") and Pennsylvania ("dangerous")), rev'd on other grounds, 454 U.S. 235 (1981). Compare Evangelinos v. Trans World Airlines, 396 F. Supp. 95 (W.D. Pa. 1975) (airline not subject to liability under Warsaw Convention for passenger injuries caused by terrorists), rev'd en banc, $550 \mathrm{~F} .2 \mathrm{~d}$ 152 (3d Cir. 1977) with Day v. Trans World Airlines, 393 F. Supp. 217 (S.D.N.Y.) (airline subject to liability under Warsaw Convention to passengers injured in same attack involved in Evangelinos), affd, 528 F.2d 31 (2d Cir. 1975), cert. denied, 429 U.S. 890 (1976).

104. One of the prerequisites to a class action is a finding that the prosecution of separate actions would create a risk of "inconsistent or varying adjudications with respect to individual members of the class which would establish incompatible standards of conduct for the party opposing the class . . . ." FED. R. Civ. P. 23(b)(1)(A).

105. See Note, Class Certification in Mass Accident Cases, supra note 40, at $1145 \mathrm{nn} .6-7$ (discussing circumstances under which limited fund threatens adequacy of recovery). 
of the rationale and procedures that assign the bulk of mass tort litigation to federal courts in the first place. Congress possesses the express authority under the full faith and credit clause to prescribe laws determining the extraterritorial effect to be given to state laws. In order to restore faith in the judicial system's ability to manage mass tort claims, Congress should use that power to enact a statute enabling and directing federal courts presiding over multidistrict mass tort litigation to make choice of law decisions consonant with the equity and efficiency principles of collective adjudication. 